\title{
Characterization of small isotropic bicelles with various compositions.
}

\section{Supporting data.}

\author{
K.S. Mineev ${ }^{1, *}$, K.D. Nadezhdin ${ }^{1,2}$, S.A. Goncharuk ${ }^{1,3}$ and A.S. Arseniev ${ }^{1,2}$
}

${ }^{1}$ Shemyakin-Ovchinnikov Institute of Bioorganic Chemistry, Russian Academy of Sciences RAS, str. Miklukho-Maklaya 16/10, Moscow, 117997 Russian Federation

${ }^{2}$ Moscow Institute of Physics and Technology, Institutsky per., 9, 141700, Dolgoprudnyi, Russian Federation

${ }^{3}$ Lomonosov Moscow State University, Leninskiye Gory, 1, Moscow, 119991, Russian Federation

*mineev@nmr.ru

Table S1. Measured parameters (diffusion coefficients at infinite dilution, radii and concentrations of detergent in monomeric form) of DMPC/DHPC bicelles. CMC* of DHPC is $15 \mathrm{mM}$.

\begin{tabular}{|c|c|c|c|c|c|c|c|}
\hline $\begin{array}{c}q^{*} \\
\left(40^{\circ} \mathrm{C}\right)\end{array}$ & $\begin{array}{c}D_{0,} \\
x 10^{-12} \mathrm{~m}^{2-1}\left(27^{\circ} \mathrm{C}\right)\end{array}$ & $x 10^{-12} \mathrm{~m}^{2} \mathrm{~s}^{-1}\left(40^{\circ} \mathrm{C}\right)$ & $\begin{array}{c}R, n m \\
\left(27^{\circ} \mathrm{C}\right)\end{array}$ & $\begin{array}{c}R, \mathrm{~nm} \\
\left(40^{\circ} \mathrm{C}\right)\end{array}$ & $\begin{array}{c}{[\text { Det }]_{\text {free, }}} \\
m M\left(27^{\circ} \mathrm{C}\right)\end{array}$ & $\begin{array}{c}{[\text { Det }]_{\text {free, }}} \\
m M\left(40^{\circ} \mathrm{C}\right)\end{array}$ & $\begin{array}{c}{[\mathrm{DMPC}]+} \\
{[\mathrm{DHPC}],} \\
m M\end{array}$ \\
\hline \hline $0.31^{\mathrm{a}}$ & $91^{\mathrm{b}}$ & 130 & 2.69 & 2.48 & $10.7^{\mathrm{c}}$ & 9.7 & 134 \\
\hline 0.40 & 87 & 122 & 2.88 & 2.74 & 9.2 & 8.6 & 112 \\
\hline 0.54 & 79 & 111 & 3.27 & 3.11 & 8.7 & 8.3 & 97 \\
\hline 0.63 & 77 & 106 & 3.43 & 3.34 & 8.2 & 7.5 & 85 \\
\hline 0.82 & 69 & 87 & 3.96 & 4.25 & 7.8 & 7.4 & 74 \\
\hline
\end{tabular}

Here and below CMC of detergents are given according to Avanti Polar Lipids Inc.

${ }^{a}$ note: $\mathrm{q}^{*}$ obtained at 27 and $40^{\circ} \mathrm{C}$ are slightly different.

${ }^{b}$ error for measured $\mathrm{D}_{0}$ and $\mathrm{R}_{\mathrm{H}}$ is ca. $1 \%$

${ }^{c}$ error for measured [Det $]_{\text {free }}$ is varied from sample to sample but never exceeds $5 \%$

Table S2. Measured parameters (diffusion coefficients at infinite dilution, radii and concentrations of detergent in monomeric form) of DMPC/CHAPS bicelles. CMC of CHAPS is $6 \mathrm{mM}$ at $20^{\circ} \mathrm{C}$.

\begin{tabular}{|c|c|c|c|c|c|c|c|}
\hline $\begin{array}{c}q^{*} \\
\left(40^{\circ} \mathrm{C}\right)\end{array}$ & $\begin{array}{c}D_{0,} \\
x 10^{-12} \mathrm{~m}^{2} \mathrm{~s}^{-1}\left(27^{\circ} \mathrm{C}\right)\end{array}$ & $\begin{array}{c}D_{0,} \\
x 10^{-12} \mathrm{~m}^{2} \mathrm{~s}^{-1}\left(40^{\circ} \mathrm{C}\right)\end{array}$ & $\begin{array}{c}R, \mathrm{~nm} \\
\left(27^{\circ} \mathrm{C}\right)\end{array}$ & $\begin{array}{c}R, \mathrm{~nm} \\
\left(40^{\circ} \mathrm{C}\right)\end{array}$ & $\begin{array}{c}{[\text { Det }]_{\text {free }}} \\
m M\left(27^{\circ} \mathrm{C}\right)\end{array}$ & $\begin{array}{c}{[\text { Det }]_{\text {free }}} \\
m M\left(40^{\circ} \mathrm{C}\right)\end{array}$ & $\begin{array}{c}{[\mathrm{DMPC}]+} \\
{[\mathrm{CHAPS}],} \\
\mathrm{mM}\end{array}$ \\
\hline \hline 0.40 & 100 & 139 & 2.36 & 2.27 & 6.2 & 7.6 & 102 \\
\hline 0.54 & 98 & 132 & 2.44 & 2.46 & 5.7 & 6.7 & 73 \\
\hline 0.66 & 95 & 126 & 2.54 & 2.60 & 4.8 & 5.8 & 66 \\
\hline 0.87 & 86 & 117 & 2.92 & 2.91 & 3.9 & 4.3 & 57 \\
\hline 1.01 & 82 & 108 & 3.14 & 3.27 & 3.2 & 3.7 & 56 \\
\hline 1.09 & 79 & 103 & 3.31 & 3.48 & 3.0 & 3.2 & 50 \\
\hline 1.16 & 72 & 97 & 3.70 & 3.89 & 3.0 & 2.8 & 49 \\
\hline 1.29 & 68 & 83 & 3.99 & 4.61 & 2.8 & 2.7 & 56 \\
\hline 1.40 & 62 & 69 & 4.53 & 5.87 & 2.6 & 2.8 & 54 \\
\hline 1.54 & 54 & 53 & 5.41 & 8.10 & 2.3 & 2.6 & 47 \\
\hline
\end{tabular}


Table S3. Measured parameters (diffusion coefficients at infinite dilution, radii and concentrations of detergent in monomeric form) of DMPC/CHAPSO bicelles. CMC of CHAPSO is $8 \mathrm{mM}$ at $20{ }^{\circ} \mathrm{C}$.

\begin{tabular}{|c|c|c|c|c|c|c|c|}
\hline $\begin{array}{c}q^{*} \\
\left(40^{\circ} \mathrm{C}\right)\end{array}$ & $x 10^{-12} \mathrm{~m}^{2} \mathrm{~s}^{-1}\left(27^{\circ} \mathrm{C}\right)$ & $x 10^{-12} \mathrm{~m}^{2} \mathrm{~s}^{-1}\left(40^{\circ} \mathrm{C}\right)$ & $\begin{array}{c}R, \mathrm{~nm} \\
\left(27^{\circ} \mathrm{C}\right)\end{array}$ & $\begin{array}{c}R, \mathrm{~nm} \\
\left(40^{\circ} \mathrm{C}\right)\end{array}$ & $\begin{array}{c}{[\text { Det }]_{\text {free, }}} \\
m M\left(27^{\circ} \mathrm{C}\right)\end{array}$ & $\begin{array}{c}{[\text { Det }]_{\text {free, }}} \\
m M\left(40^{\circ} \mathrm{C}\right)\end{array}$ & $\begin{array}{c}{[D M P C]+} \\
{[\mathrm{CHAPSO},} \\
m M\end{array}$ \\
\hline \hline 0.52 & 94 & 131 & 2.56 & 2.46 & 5.6 & 6.0 & 86 \\
\hline 0.72 & 89 & 121 & 2.79 & 2.75 & 4.1 & 4.6 & 67 \\
\hline 0.92 & 80 & 107 & 3.23 & 3.28 & 3.1 & 3.5 & 105 \\
\hline 1.04 & 75 & 102 & 3.55 & 3.53 & 2.8 & 3.1 & 66 \\
\hline 1.42 & 55 & 60 & 5.28 & 6.99 & 2.5 & 2.6 & 61 \\
\hline
\end{tabular}

Table S4. Measured parameters (diffusion coefficients at infinite dilution, radii and concentrations of detergent in monomeric form) of DMPC/cholate bicelles. CMC of sodium cholate is $14 \mathrm{mM}$ at $\mathrm{pH} 7.5$.

\begin{tabular}{|c|c|c|c|c|c|c|c|}
\hline $\begin{array}{c}q^{*} \\
\left(40^{\circ} \mathrm{C}\right)\end{array}$ & $x 10^{-12} \mathrm{~m}^{2} \mathrm{~s}^{-1}\left(27^{\circ} \mathrm{C}\right)$ & $x 10^{-12} \mathrm{~m}^{2} \mathrm{~s}^{-1}\left(40^{\circ} \mathrm{C}\right)$ & $\begin{array}{c}R, n m \\
\left(27^{\circ} \mathrm{C}\right)\end{array}$ & $\begin{array}{c}R, n m \\
\left(40^{\circ} \mathrm{C}\right)\end{array}$ & $\begin{array}{c}{[\text { Det }]_{\text {free, }}} \\
m M\left(27^{\circ} \mathrm{C}\right)\end{array}$ & $\begin{array}{c}{[\text { Det }]_{\text {free, }}} \\
m M\left(40^{\circ} \mathrm{C}\right)\end{array}$ & $\begin{array}{c}{[\text { DMPC }+} \\
{[\text { cholate }],} \\
m M\end{array}$ \\
\hline \hline 0.53 & 91 & 124 & 2.69 & 2.66 & 10.4 & 11.3 & 90 \\
\hline 0.71 & 81 & 115 & 3.15 & 2.99 & 10.0 & 10.9 & 85 \\
\hline 1.03 & 75 & 106 & 3.55 & 3.33 & 9.1 & 9.6 & 63 \\
\hline 1.27 & 69 & 96 & 3.98 & 3.83 & 8.3 & 8.3 & 61 \\
\hline 1.55 & 67 & 98 & 4.10 & 3.72 & 7.9 & 8.1 & 56 \\
\hline
\end{tabular}

Table S5. Measured parameters (diffusion coefficients at infinite dilution, radii and concentrations of detergent in monomeric form) of DPPC/CHAPS bicelles.

\begin{tabular}{|c|c|c|c|c|c|c|c|}
\hline $\begin{array}{c}q^{*} \\
\left(40^{\circ} \mathrm{C}\right)\end{array}$ & $x 10^{-12} \mathrm{~m}^{2} \mathrm{~s}^{-1}\left(27^{\circ} \mathrm{C}\right)$ & $x 10^{-12} \mathrm{~m}^{2} \mathrm{~s}^{-1}\left(40^{\circ} \mathrm{C}\right)$ & $\begin{array}{c}R, \mathrm{~nm} \\
\left(27^{\circ} \mathrm{C}\right)\end{array}$ & $\begin{array}{c}R, \mathrm{~nm} \\
\left(40^{\circ} \mathrm{C}\right)\end{array}$ & $\begin{array}{c}{[\text { Det }]_{\text {free }}} \\
m M\left(27^{\circ} \mathrm{C}\right)\end{array}$ & $\begin{array}{c}{[\text { Det }]_{\text {free, }}} \\
m M\left(40^{\circ} \mathrm{C}\right)\end{array}$ & $\begin{array}{c}{[\mathrm{DPPC}]+} \\
{[\mathrm{CHAPS}],} \\
\mathrm{mM}\end{array}$ \\
\hline \hline 0.41 & 94 & 128 & 2.49 & 2.45 & 7.1 & 7.8 & 77 \\
\hline 0.58 & 89 & 121 & 2.68 & 2.67 & 6.1 & 6.6 & 60 \\
\hline 0.77 & 82 & 112 & 3.02 & 3.01 & 5.2 & 5.3 & 53 \\
\hline 0.88 & 78 & 106 & 3.27 & 3.24 & 5.0 & 4.4 & 52 \\
\hline 1.04 & 73 & 101 & 3.56 & 3.46 & 4.8 & 3.9 & 45 \\
\hline $\begin{array}{c}1.27 \\
(1.39)\end{array}$ & 68 & 86 & 3.95 & 4.28 & 5.2 & 3.5 & 45 \\
\hline
\end{tabular}

Table S6. Measured parameters (diffusion coefficients at infinite dilution, radii and concentrations of detergent in monomeric form) of POPC/CHAPS bicelles.

\begin{tabular}{|c|c|c|c|c|c|c|c|}
\hline $\begin{array}{c}q^{*} \\
\left(40^{\circ} \mathrm{C}\right)\end{array}$ & $x 10^{-12} \mathrm{~m}^{2} \mathrm{~s}^{-1}\left(27^{\circ} \mathrm{C}\right)$ & $x 10^{-12} \mathrm{~m}^{2} \mathrm{~s}^{-1}\left(40^{\circ} \mathrm{C}\right)$ & $\begin{array}{c}R, n m \\
\left(27^{\circ} \mathrm{C}\right)\end{array}$ & $\begin{array}{c}R, \mathrm{~nm} \\
\left(40^{\circ} \mathrm{C}\right)\end{array}$ & $\begin{array}{c}{[\text { Det }]_{\text {free, }}} \\
m M\left(27^{\circ} \mathrm{C}\right)\end{array}$ & $\begin{array}{c}{[\text { Det }]_{\text {free, }}} \\
m M\left(40^{\circ} \mathrm{C}\right)\end{array}$ & $\begin{array}{c}{[\mathrm{POPC}]+} \\
{[\mathrm{CHAPS}],} \\
\mathrm{mM}\end{array}$ \\
\hline \hline 0.65 & 84 & 118 & 2.94 & 2.79 & 5.2 & 5.9 & 54 \\
\hline 1.04 & 54 & 70 & 5.39 & 5.67 & 3.5 & 3.9 & 47 \\
\hline
\end{tabular}


<smiles>[CH][C@@H](COC(=O)CCCCC)COP(=O)([O-])OCC[N+](C)(C)C</smiles><smiles>CCCCCCCCCCCCCC(=O)OC[C@@H](COP(=O)([O-])OCC[N+](C)(C)C)OC(=O)CCCCCCCCCCCC</smiles><smiles>CCCCCCCC/C=C\CCCCCCCCCCCC(=O)OCCCOP(=O)([O-])OCC[N+](C)(C)C</smiles><smiles>CCCCCCCCCCCCCCCCCCCCCC(=O)OCCCOP(=O)([O-])OCC[N+](C)(C)C</smiles><smiles>CC(CCC(=O)NCCC[N+](C)(C)CCCS(=O)(=O)[O-])[C@H]1CCC2C3C(C[C@H](O)[C@@]21C)[C@@]1(C)CC[C@H](O)C[C@H]1C[C@H]3O</smiles><smiles>CC(CCC(=O)NCCC[N+](C)(C)CC(O)CS(=O)(=O)[O-])[C@H]1CCC2C3C(C[C@H](O)[C@]21C)[C@@]1(C)CC[C@@H](O)C[C@H]1C[C@H]3O</smiles><smiles>CC(CCC(=O)O[Al])[C@H]1CCC2C3C(C[C@H](O)[C@]21C)[C@@]1(C)CC[C@@H](O)C[C@H]1C[C@H]3O</smiles>

DHPC

1,2-dihexanoyl-sn-glycero-3-phosphocholine CMC $15 \mathrm{mM}$

\section{DMPC}

1,2-dimyristoyl-sn-glycero-3-phosphocholine

\section{POPC}

1-palmitoyl-2-oleoyl-sn-glycero-3-phosphocholine

\section{DPPC}

1,2-dipalmitoyl-sn-glycero-3-phosphocholine

\section{CHAPS}

$\mathrm{CMC} 6 \mathrm{mM}\left(20-25^{\circ} \mathrm{C}\right)$

\section{CHAPSO}

$\mathrm{CMC} 8 \mathrm{mM}\left(20-25^{\circ} \mathrm{C}\right)$

\section{Sodium cholate} CMC $9-15 \mathrm{mM}\left(20-25^{\circ} \mathrm{C}\right)$

Figure S1. Structures of lipids and detergents used in the current study. Critical micelle concentrations (CMCs) are indicated. 

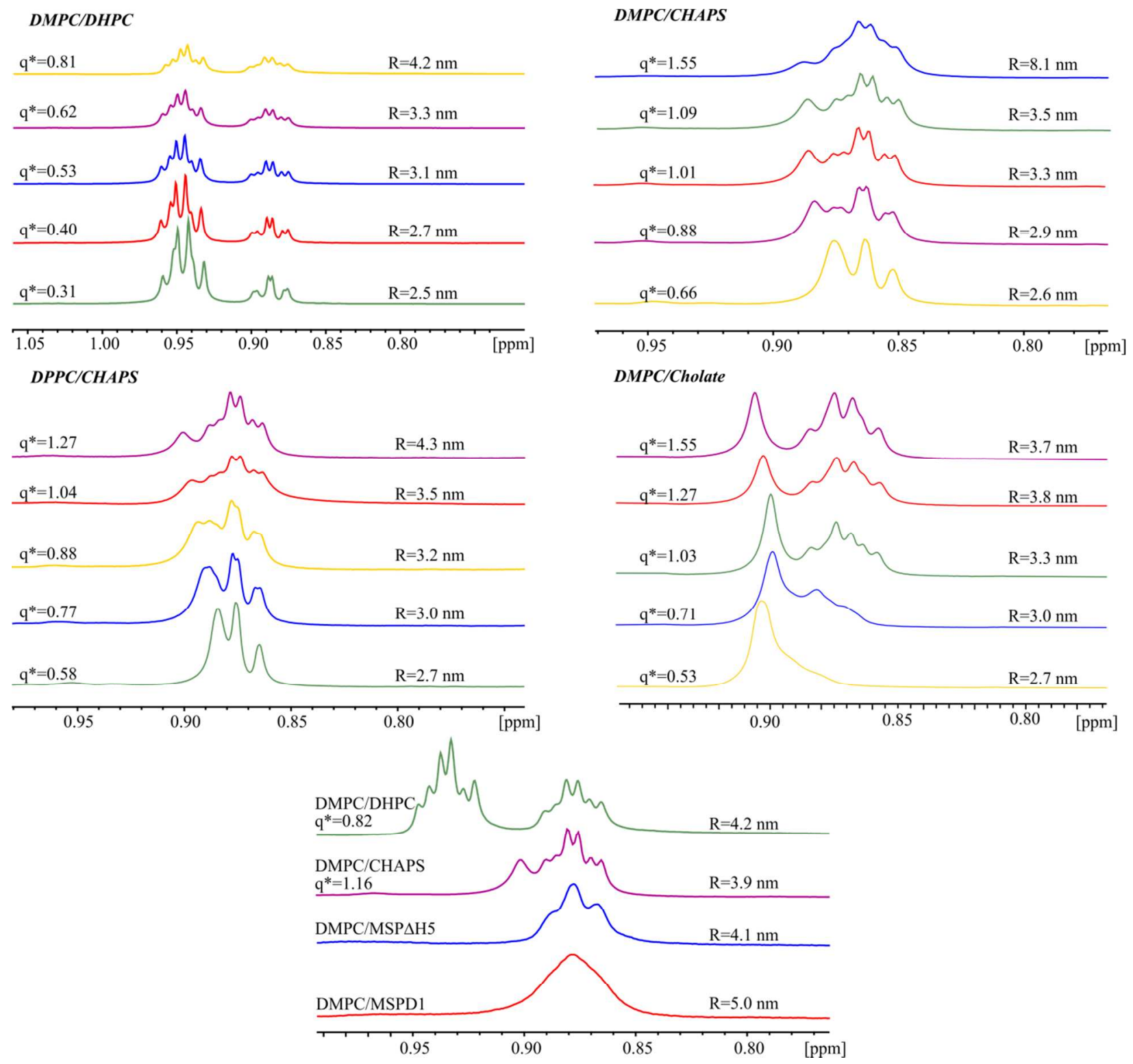

Figure S2. Signal from the lipid methyl groups in bicelles formed of various lipids in $1 \mathrm{H}$ NMR spectra $\left(700 \mathrm{MHz}, 40{ }^{\circ} \mathrm{C}\right) . \mathrm{q}^{*}$ ratios, used lipids and detergents and corresponding bicelle radii are indicated. Comparison of methyl signals lineshapes, observed in $1 \mathrm{H}$ spectra of MSPD1 and MSPAH5 LPNs, with lineshapes observed in DMPC/DHPC and DMPC/CHAPS bicelles with similar size is shown at bottom. 
A
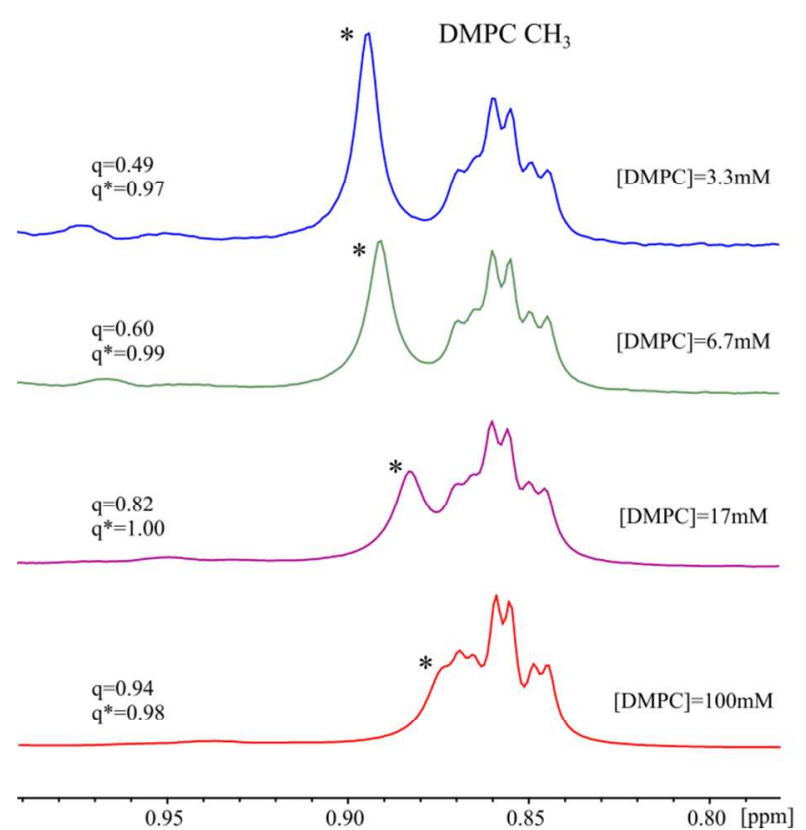

B

diluted by $\mathrm{H}_{2} \mathrm{O}$

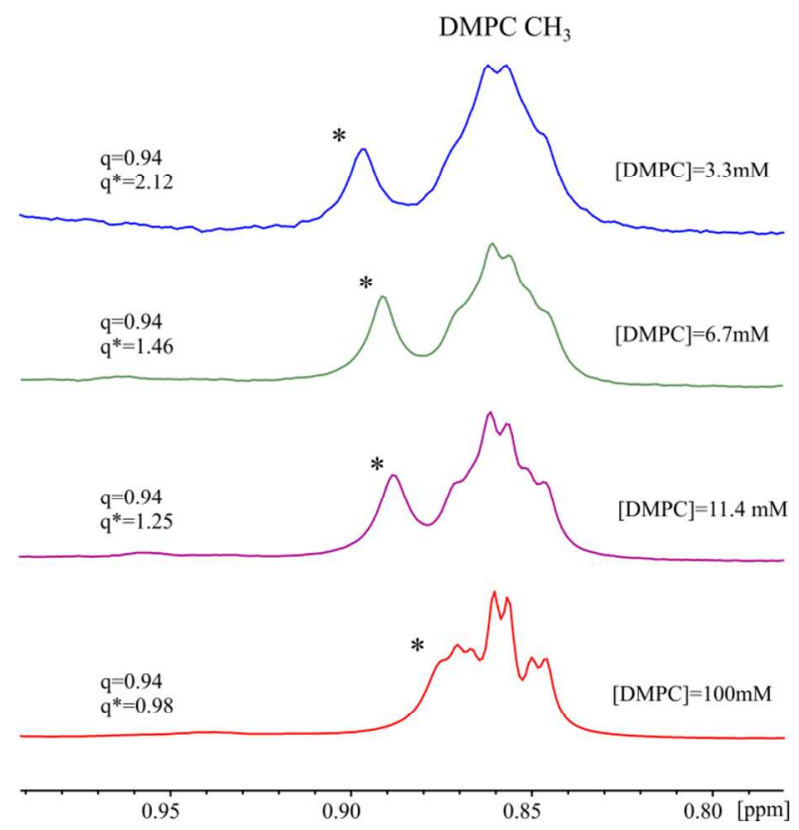

Figure S3. Appearance of the signal in ${ }^{1} \mathrm{H}$ NMR spectra, corresponding to DMPC methyl group, in DMPC/CHAPS bicelles diluted by either $3.3 \mathrm{mM}$ CHAPS solution ( $\mathbf{A}$, corresponds to [Det $]_{\text {free }}$ in $\mathrm{q}^{*}=1$ DMPC/CHAPS bicelles) or by pure water (B). Magnitudes of $q$ and $q^{*}$ and concentrations of DMPC are shown. Signal form one of the CHAPS methyl groups is indicated by asterisk and is changing its position due to the fast exchange of CHAPS between the water-soluble and bicelle-bound states. Linewidth and splitting of the signal, corresponding to DMPC methyl group, are preserved, when the initial sample is diluted by the $3.3 \mathrm{mM}$ CHAPS solution, indicating that the morphology and packing of lipids in DMPC/CHAPS bicelles are unchanged even at high dilution. When diluted by water, bicelles grow in size, which results in substantial line broadening and changes in lineshapes of signals in $1 \mathrm{H}$ NMR spectra. Experiments were performed at $40{ }^{\circ} \mathrm{C}$ on $700 \mathrm{MHz}$ NMR spectrometer. 
DMPC/DHPC
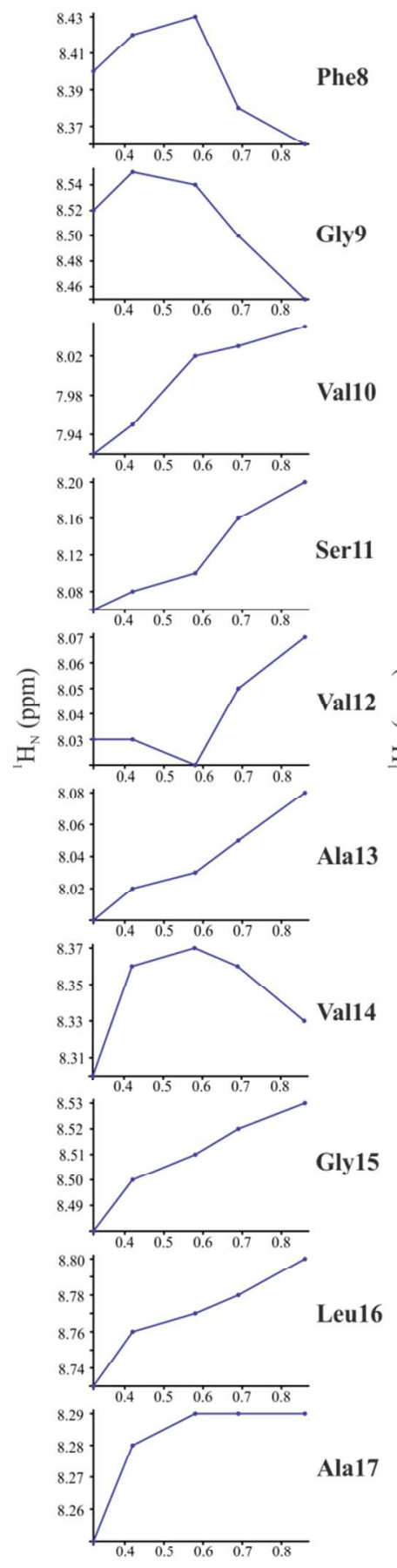

DMPC/DHPC ratio (q value)
DMPC/CHAPS
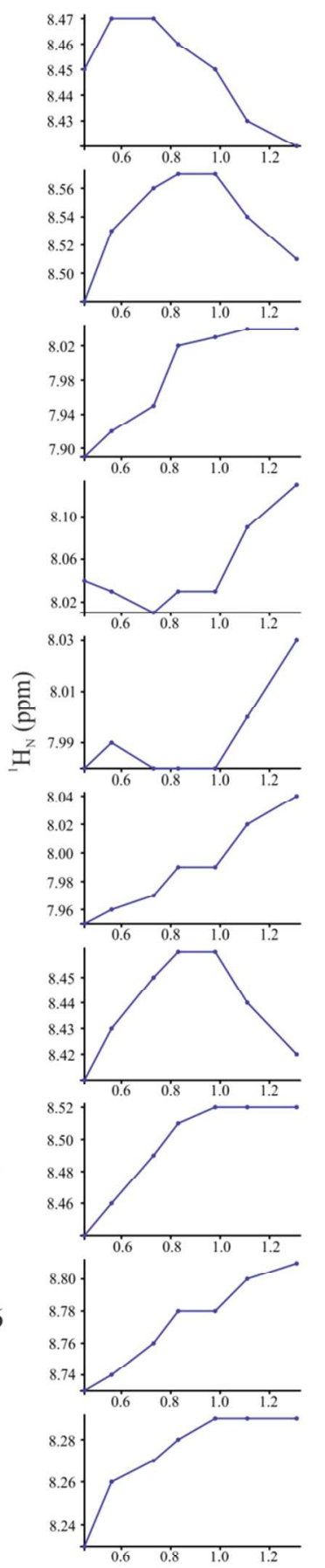

DMPC/CHAPS ratio (q value)
DMPC/DHPC

DMPC/CHAPS
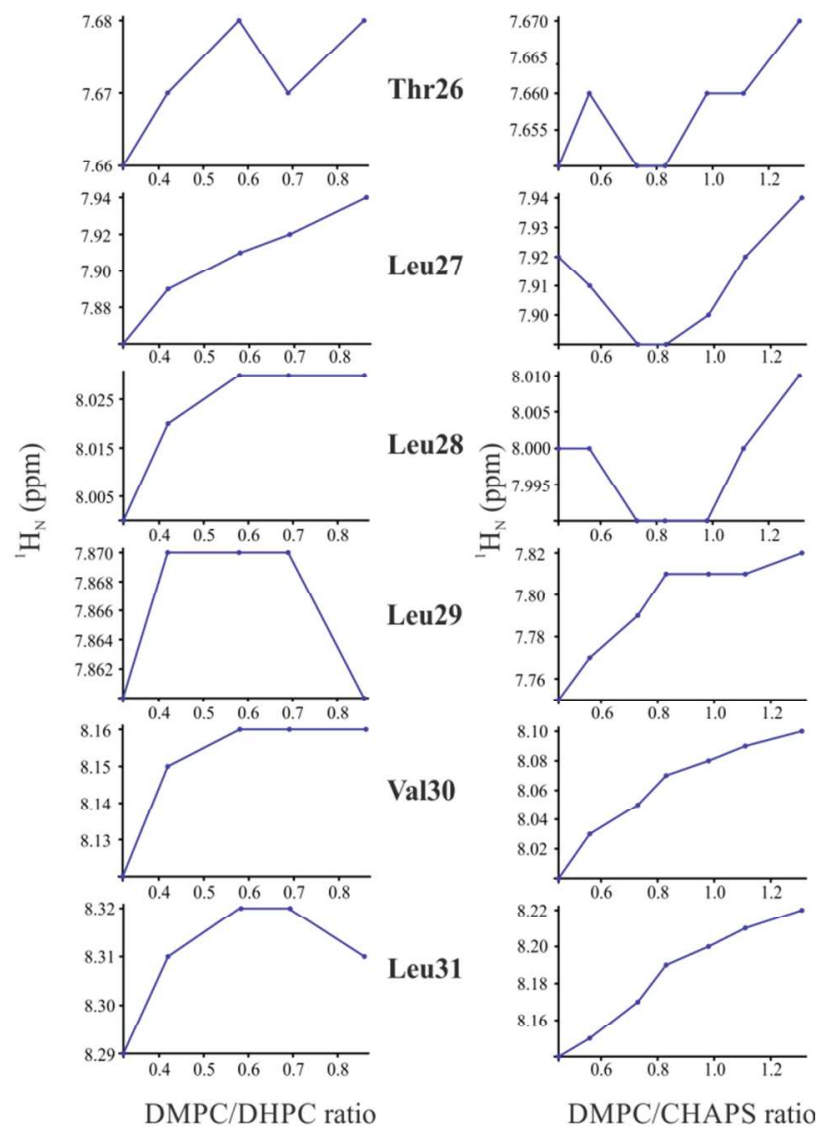

(q value)
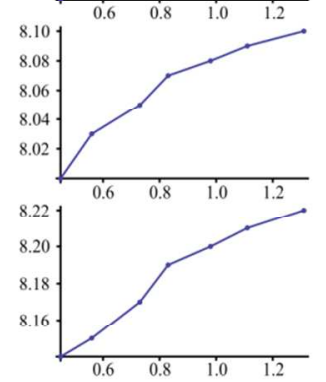

DMPC/CHAPS ratio (q value)

Figure S4. Dependence of the NMR chemical shifts of TrkA-TM residues on the $q^{*}$ ratio in DMPC/DHPC and DMPC/CHAPS bicelles at $40{ }^{\circ} \mathrm{C}$. Note that almost all signals shift downfield with the growth of $\mathrm{q}^{*}$. This indicates the shortening of hydrogen bonds and slight shrinkage of the TM helix. 


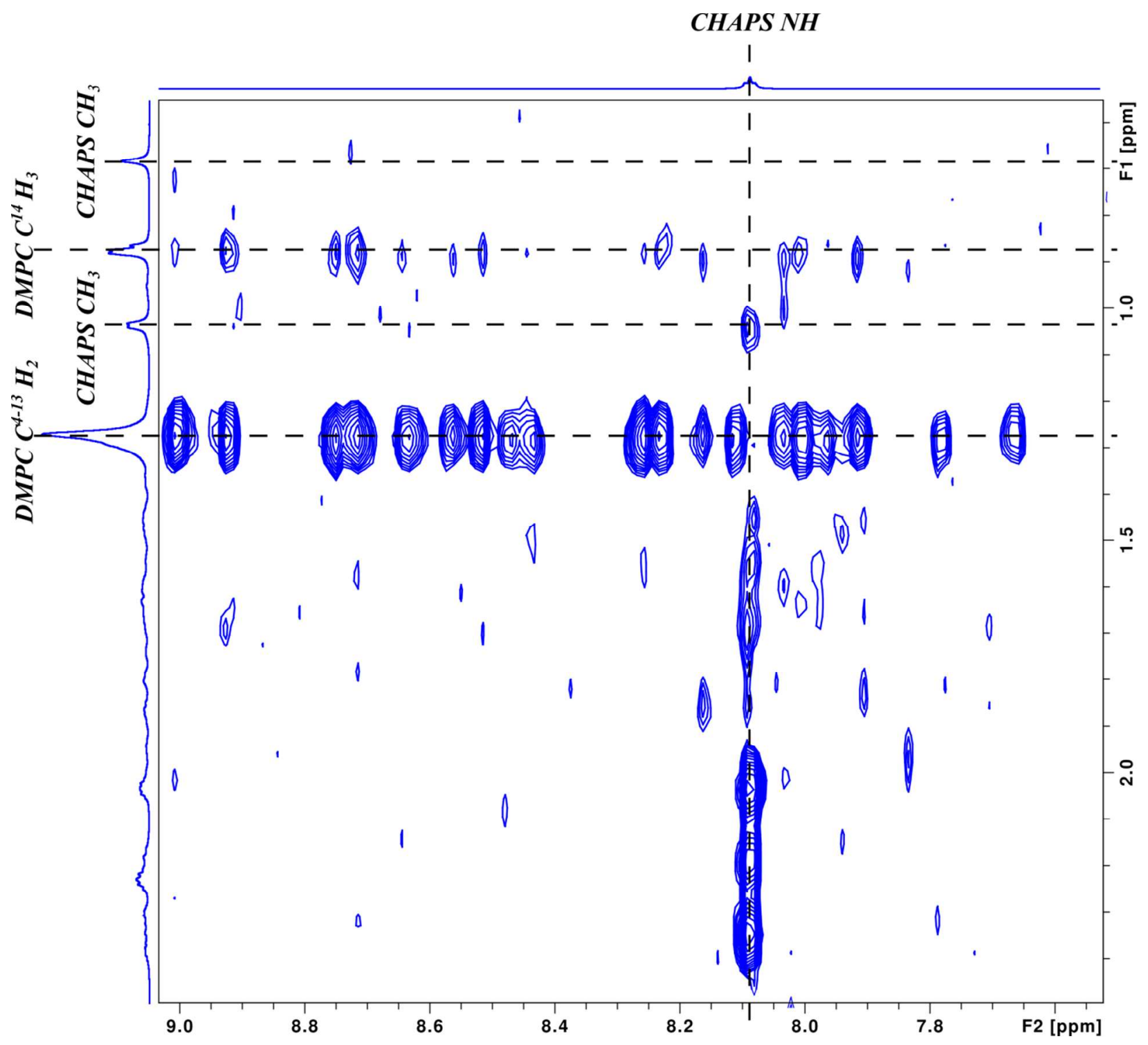

Figure S5. Fragment of $\left\{{ }^{1} \mathrm{H},{ }^{1} \mathrm{H}\right\}$ projection of a $3 \mathrm{D}{ }^{15} \mathrm{~N}$-edited NOESY-HSQC NMR spectrum of ${ }^{15} \mathrm{~N},{ }^{2} \mathrm{H}-\mathrm{TrkA}$ TM in $\mathrm{q}^{*}=0.56 \mathrm{DMPC} / \mathrm{CHAPS}$ bicelles. Horizontal dashed lines denote frequencies, corresponding to methyl and methylene groups of CHAPS and DMPC, vertical line shows the frequency, corresponding to the signal of CHAPS N-H group, which is observed in 3D spectrum at natural abundance. Only proteinDMPC interactions are observed. 